\title{
Long-term response after electrochemotherapy in patients with relapsed or refractory cutaneous melanoma
}

\author{
Nicola Mozzillo', Corrado Caracò ${ }^{1}$, Ugo Marone ${ }^{1 *}$, Ester Simeone ${ }^{2}$, Stefano Mori ${ }^{1}$, Lucia Benedetto ${ }^{1}$, \\ Gianluca Di Monta ${ }^{1}$, Maria Luisa Di Cecilia ${ }^{1}$, Massimiliano Di Marzo ${ }^{1}$, Gerardo Botti ${ }^{3}$, Paolo Antonio Ascierto ${ }^{2}$ \\ From Melanoma Bridge meeting 2013 \\ Naples, Italy. 5-8 December 2013
}

\section{Background}

Treatment of early and multiple cutaneous unresectable recurrences is a major therapeutic problem with around $80 \%$ of patients relapsing within 5 years [1]. For lesions refractory to elective treatments, electrochemotherapy (ECT) involving electroporation combined with antineoplastic drug treatment appears to be a new potential option [2]. This study was undertaken to analyze the short- and long-term responses of lesions treated with ECT with intravenous injection of bleomycin in melanoma patients with in-transit disease or distant cutaneous metastases.

\section{Materials and methods}

Between January 2007 and September 2012, 60 patients with relapsed and refractory cutaneous melanoma metastases or in-transit disease underwent 100 courses of ECT with intravenous injection of bleomycin. Response to treatment was evaluated three months after ECT. A longlasting response was defined as no cutaneous or in-transit relapse after a minimum of six months.

\section{Results}

Three months after ECT, a complete response was observed in 29 patients $(48.4 \%)$, a partial response in 23 patients $(38.3 \%)$ and no change or progressive disease in 8 patients $(13.3 \%)$. The objective response rate of all treated lesions was $86.6 \%$. Thirteen patients $(44.8 \%$ of complete responders) experienced a long-lasting response

\footnotetext{
* Correspondence: u.marone@istitutotumori.na.it

'Unit of Surgery "Melanoma - Soft Tissues", National Cancer Institute, Naples, Italy

Full list of author information is available at the end of the article
}

to ECT and were disease-free after a mean duration of follow-up of 27.5 months.

\section{Conclusions}

The favorable outcome obtained in the present study demonstrates that ECT is a reliable, and effective procedure that provides long-term benefit in terms of curative and palliative treatment for unresectable cutaneous lesions without adversely impacting the quality of life of patients [3-7].

\section{Authors' details}

'Unit of Surgery "Melanoma - Soft Tissues", National Cancer Institute, Naples, Italy. ${ }^{2}$ Unit of Medical Oncology, National Cancer Institute, Naples, Italy. ${ }^{3}$ Unit of Pathology, National Cancer Institute, Naples, Italy.

\section{Published: 6 May 2014}

\section{References}

1. Leon P, Daly J, Synnestvedt M, Schultz DJ, Elder DE, Clark WH Jr: The prognostic implications of microscopic satellites in patients withclinical Stage I melanoma. ArchSurg 1991, 126:1461-68.

2. Marty M, Garbay JM, Gehl J, et al: Electrochemotherapy an easy, highly effective and safe treatment of cutaneous and subcutaneous metastases: results of ESOPE (European Standard Operating Procedures of Electrochemotherapy) study. Eur J Cancer 2006, 4:3-13.

3. Sersa G, Miklavcic D, Cemazar M, Rudolf Z, Pucihar G, Snoj M: Electrochemotherapy in treatment of tumors. Eur J SurgOncol 2007, 34:232-40.

4. Quaglino P, Mortera C, Osella-Abate S, et al: Electrochemotherapy with intravenous bleomycin in the local treatment of skin melanoma metastases. Ann Surg Oncol 2008, 15:2215-22.

5. Sersa G, Stabuc B, Cemazar M, Miklavcic D, Rudolf Z: Electrochemotherapy with cisplatin: systemic antitumor effectiveness of cisplatin can be potentiated locally by the application of electric pulses in the treatment of malignant melanoma skin metastases. Melanoma Res 2000, 10:381-85.

6. Kaehler KC, Egberts F, Hauschild A: Electrochemotherapy in symptomatic melanoma skin metastases: intraindividual comparison with conventional surgery. Dermatol Surg 2010, 36:1200-02. 
7. Mozzillo N, Caracò C, Mori S, et al: Use of

neoadjuvantelectrochemotherapy to treat a large metastatic lesion of the cheek in a patient with melanoma. J Trans/ Med 2012, 10:131.

doi:10.1186/1479-5876-12-S1-P1

Cite this article as: Mozzillo et al: Long-term response after

electrochemotherapy in patients with relapsed or refractory cutaneous melanoma. Journal of Translational Medicine 2014 12(Suppl 1):P1.

Submit your next manuscript to BioMed Central and take full advantage of:

- Convenient online submission

- Thorough peer review

- No space constraints or color figure charges

- Immediate publication on acceptance

- Inclusion in PubMed, CAS, Scopus and Google Scholar

- Research which is freely available for redistribution

Submit your manuscript at www.biomedcentral.com/submit
Ciomed Central 